\title{
ENKRIPSI DAN DEKRIPSI FILE DENGAN ALGORITMA BLOWFISH PADA PERANGKAT MOBILE BERBASIS ANDROID
}

\author{
Siswo Wardoyo*, Zaldi Imanullah, Rian Fahrizal \\ Jurusan Teknik Elektro, FakultasTeknik Universitas Sultan Ageng Tirtayasa \\ Jl. Jendral Sudirman Km.3 Cilegon - Banten \\ *Corresponding author, e-mail : siswo@untirta.ac.id
}

\begin{abstract}
Abstrak - Kriptografi merupakan salah satu cara yang digunakan untuk mengamankan data dalam bentuk file dengan mengenkripsi file sehingga orang lain tidak berhak mengetahui file yang sifatnya pribadi dan rahasia. Salah satu metode kriptografi adalah algoritma Blowfish yang merupakan algoritma yang menggunakan kunci simetris untuk melakukan enkripsi dan dekripsi. Aplikasi yang dibangun ini dapat melakukan enkripsi file berbentuk gambar, video, dan dokumen. Aplikasi ini dapat berjalan pada ponsel yang minimal memiliki sistem operasi Android versi 2.3. Perangkat lunak yang digunakan untuk membangun aplikasi ini adalah Eclipse. Hasil dari penelitian ini menunjukkan bahwa aplikasi yang dibangun mampu melakukan enkripsi dan dekripsi dengan baik. Hasil enkripsi file membuat file menjadi tidak diketahui lagi maknanya. Dengan menggunakan kunci berjumlah 72 bit atau 9 karakter dibutuhkan waktu $1,49 \times 10^{8}$ tahun untuk membongkarnya dengan kecepatan komputasinya adalah $10^{6} \mathrm{key} / \mathrm{sec}$.
\end{abstract}

Kata kunci: kriptografi, algoritma Blowfish, kunci simteris, Android, enkripsi, dekripsi.

\begin{abstract}
Cryptography is one of the ways used to secure data in the form of a file with encrypt files so that others are not entitled to know the file is private and confidential. One method is the algorithm Blowfish Cryptography which is a symmetric key using the algorithm to perform encryption and decryption. Applications that are built can perform file encryption-shaped images, videos, and documents. These applications can be running on a mobile phone that has a minimal operating system Android version 2.3. The software used to build these applications is Eclipse. The results of this research indicate that applications built capable of performing encryption and decryption. The results file encryption makes files into another unknown meaning. By using the keys numbered 72 bits or 9 character takes 1,49x108 years to break it with the speed it's computation is $106 \mathrm{key} / \mathrm{sec}$.
\end{abstract}

Keywords: cryptography, algorithm Blowfish, symmetric key, Android, encryption, decryption

Copyright () 2016 JNTE. All rights reserved

\section{PENDAHULUAN}

Pesatnya perkembangan media telekomunikasi dan informasi di berbagai bidang selaras dengan tingginya tingkat aktivitas dan kebutuhan manusia akan informasi dalam kehidupan sehari-hari[1]. Kebutuhan akan layanan telekomunikasi dengan kecepatan transmisi yang tinggi serta fleksibilitas dalam hal penggunaan perangkat layanan mendorong para penyedia jasa layanan dan perangkat telekomunikasi untuk senantiasa mengembangkan kemampuan dari teknologi yang dimilikinya, khususnya layanan berbasis nirkabel[2].

Pada saat ini, penggunaan perangkat mobile sudah menjadi trend di masyarakat dunia. Perangkat mobile yang beredar saat ini sangat menakjubkan, sehingga mempunyai dampak dalam meningkatkan efektifitas dan efisiensi dalam melakukan setiap pekerjaan. Sistem operasi untuk perangkat mobile semakin berkembang. Android merupakan salah satu sistem operasi mobile buatan Google yang kini sangat populer dan banyak digunakan orangorang. Pengguna Android mempunyai kemudahan untuk mendapatkan aplikasiaplikasi yang diinginkan[3].

Android juga merupakan sistem operasi yang berbasis perangkat lunak yang dapat dikembangkan secara terbuka (open source) sehingga banyak pengembang yang kini turut ikut mengembangkan aplikasi untuk Android. Perangkat mobile yang dijalankan oleh Android tidak hanya menjadi alat komunikasi saja, melainkan dapat menjadi self-assistant, dapat 
digunakan untuk gaming, browsing, pemutar musik dan video, memotret gambar dan merekam video, media penyimpanan, modem, bahkan sampai internet banking [4].

Dalam suatu media penyimpanan, terdapat suatu data penting atau rahasia yang tidak semua orang boleh mengetahuinya. Data-data penting yang hanya boleh diketahui oleh pemiliknya saja antara lain dokumen, video, foto, akun email, akun jejaring sosial, akun kartu kredit, akun internet banking. Apalagi saat proses pengiriman file melalui media internet maupun saat perangkat mobile itu hilang, membuat pemiliknya sangat riskan kehilangan data-data pentingnya[4].

Oleh karena itu, dalam penelitian ini akan coba dibuat sebuah aplikasi pengamanan data berupa dokumen, gambar, dan video dengan menggunakan metode algoritma Blowfish untuk mengenkripsi data yang berjalan pada sistem operasi Android sehingga pemilik merasa aman untuk menyimpan datanya.

\section{TINJAUAN PUSTAKA}

\subsection{Enkripsi dan Dekripsi}

Proses menyandikan plainteks menjadi cipherteks[5] disebut enkripsi (encryption) atau enciphering (standar nama menurut ISO 74982). Sedangkan proses mengembalikan cipherteks menjadi plainteks semula dinamakan dekripsi (decryption) atau deciphering (standar nama menurut ISO 7498-2). Enkripsi dan dekripsi dapat diterapkan baik pada pesan yang dikirim maupun pada pesan tersimpan[6][7].

Istilah encryption of data in motion mengacu pada enkripsi pesan yang ditransmisikan melalui saluran komunikasi, sedangkan istilah encryption of data at-rest mengacu pada enkripsi dokumen yang disimpan di dalam storage. Gambar 1 menunjukkan skema enkripsi dan dekripsi.

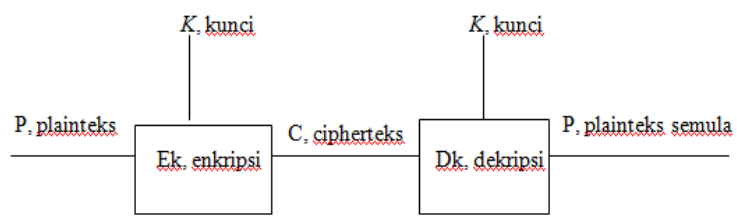

Gambar 1. Skema enkripsi dan dekripsi[6][8][9]

\subsection{Algoritma Blowfish}

Blowfish termasuk dalam enkripsi block Chiper 64-bit dengan panjang kunci minimal 32- bit sampai 448-bit[10]. Blowfish alias "OpenPGP.Cipher.4" merupakan enkripsi yang termasuk dalam golongan Symmetric Cryptosystem [5], metode enkripsinya mirip dengan DES (DES like Cipher) diciptakan oleh seorang Cryptanalyst bernama Bruce Schneier Presiden perusahaan Counterpane Internet Security, Inc (Perusahaan konsultan tentang kriptografi dan keamanan komputer) dan dipublikasikan tahun 1994[11]. Dibuat untuk digunakan pada komputer yang mempunyai mikroprosesor besar (32-bit keatas dengan cache data yang besar).

Blowfish dikembangkan untuk memenuhi kriteria desain yang cepat dalam implementasinya dimana pada keadaan optimal dapat mencapai 26 clock cycle per Byte, kompak dimana dapat berjalan pada memori kurang dari $5 \mathrm{~KB}$, sederhana dalam algoritmanya sehingga mudah diketahui kesalahannya, dan keamanan yang variable panjang kunci bervariasi (minimum 32 bit, maksimum 448 bit, multiple 8 bit, default 128 bit)[4][12].

\subsubsection{Key Expansion}

Berfungsi merubah kunci (minimum 32bit, maksimum 448-bit) menjadi beberapa array subkunci (subkey) dengan total 4168 Byte (18x32-bit untuk P-array dan 4x256x32-bit untuk S-box sehingga totalnya 33344 bit atau 4168 Byte)[4]. Kunci disimpan dalam K-array:

$$
\mathrm{K} 1, \mathrm{~K} 2, \ldots \mathrm{Kj} 1 \leq \mathrm{j} \leq 14
$$

Kunci-kunci ini yang dibangkitkan (generate) dengan menggunakan subkunci yang harus dihitung terlebih dahulu sebelum enkripsi atau dekripsi data. Sub-sub kunci yang digunakan terdiri dari:

P-array yang terdiri dari 18 buah 32-bit subkunci,

$$
\mathrm{P} 1, \mathrm{P} 2, \ldots, \mathrm{P} 18
$$

S-box yang terdiri dari 4 buah 32-bit, masingmasing memiliki 256 entri:

$$
\begin{aligned}
& \mathrm{S}_{1,0}, \mathrm{~S}_{1,1}, \mathrm{~S}_{1,2}, \mathrm{~S}_{1,3}, \ldots \ldots \ldots \ldots \ldots . . . \mathrm{S}_{1,255} \\
& \mathrm{~S}_{2,0}, \mathrm{~S}_{2,1}, \mathrm{~S}_{2,2}, \mathrm{~S}_{2,3}, \ldots \ldots \ldots \ldots \ldots . . . \mathrm{S}_{2,255} \\
& \mathrm{~S}_{3,0}, \mathrm{~S}_{3,1}, \mathrm{~S}_{3,2}, \mathrm{~S}_{3,3}, \ldots \ldots \ldots \ldots \ldots . . . . \mathrm{S}_{3,255} \\
& \mathrm{~S}_{4,0}, \mathrm{~S}_{4,1}, \mathrm{~S}_{4,2}, \mathrm{~S}_{4,3}, \ldots \ldots \ldots \ldots \ldots . . . \mathrm{S}_{4,255}
\end{aligned}
$$

Langkah-langkah perhitungan atau pembangkitan subkunci tersebut adalah sebagai berikut:

1. Inisialisasi P-array yang pertama dan juga empat S-box, berurutan, dengan string yang 
telah pasti. String tersebut terdiri dari digitdigit heksadesimal dari phi, tidak termasuk angka tiga di awal.

2. XOR-kan P1 dengan 32-bit awal kunci, XOR-kan P2 dengan 32-bit berikutnya dari kunci, dan seterusnya untuk semua bit kunci. Ulangi siklus seluruh bit kunci secara berurutan sampai seluruh $\mathrm{P}$-array ter-XORkan dengan bit-bit kunci. Atau jika disimbolkan : $\mathrm{P} 1=\mathrm{P} 1 \oplus \mathrm{K} 1, \quad \mathrm{P} 2=\mathrm{P} 2 \oplus$ $\mathrm{K} 2, \mathrm{P} 3=\mathrm{P} 3 \oplus \mathrm{K} 3, \ldots \mathrm{P} 14=\mathrm{P} 14 \oplus \mathrm{K} 14$, $\mathrm{P} 15=\mathrm{P} 15 \oplus \mathrm{K} 1, \ldots \mathrm{P} 18=\mathrm{P} 18 \oplus \mathrm{K} 4$. Keterangan : $\bigoplus$ adalah simbol untuk XOR.

3. Enkripsikan string yang seluruhnya nol dengan algoritma Blowfish, menggunakan subkunci yang telah dideskripsikan pada langkah 1 dan 2.

4. Gantikan P1 dan P2 dengan output dari langkah 3.

5. Enkripsikan keluaran langkah 3 menggunakan algoritma Blowfish dengan subkunci yang telah dimodifikasi.

6. Gantikan P3 dan P4 dengan output dari langkah 5.

7. Lanjutkan langkah-langkah $a-f$, gantikan seluruh elemen P-array dan kemudian keempat S-box secara berurutan, dengan hasil keluaran algoritma Blowfish yang terusmenerus berubah.

Total terdapat 521 iterasi untuk menghasilkan subkunci dan membutuhkan memori sebesar 4KB.

\subsubsection{Enkripsi Data}

Terdiri dari iterasi fungsi sederhana (Feistel Network) sebanyak 16 kali putaran (iterasi), masukannya adalah 64 bit elemen data $X$. Setiap putaran terdiri dari permutasi kunci dependent dan substitusi kunci dan data dependent. Semua operasi adalah penambahan (addition) dan XOR pada variabel 32-bit. Operasi tambahan lainnya hanyalah empat penelusuran tabel array berindeks untuk setiap putaran. Langkahnya adalah seperti berikut:

1. Bagi X menjadi dua bagian yang masingmasing terdiri dari 32-bit: XL, XR.

2. Lakukan langkah berikut

For $\mathrm{i}=1$ to 16 :

$\mathrm{XL}=\mathrm{XL} \oplus \mathrm{Pi}$

$\mathrm{XR}=\mathrm{F}(\mathrm{XL}) \oplus \mathrm{XR}$

3. Tukar XL dan XR
4. Setelah iterasi ke-16, tukar XL dan XR lagi untuk melakukan membatalkan pertukaran terakhir.

5. Lalu lakukan

$$
\mathrm{XR}=\mathrm{XR} \oplus \mathrm{P} 17
$$$$
\mathrm{XL}=\mathrm{XL} \oplus \mathrm{P} 18
$$

6. Terakhir, gabungkan kembali XL dan XR untuk mendapatkan cipherteks.

Dekripsi sama persis dengan enkripsi, kecuali bahwa P1, P2,.., P18 digunakan pada urutan yang berbalik (reverse). Algoritmanya dapat dinyatakan sebagai berikut:

$$
\begin{aligned}
& \text { for } \mathrm{i}=1 \text { to } 16 \text { do } \\
& \mathrm{XRi}=\mathrm{XLi}-1 \oplus \text { P19-i; } \\
& \mathrm{XLi}=\mathrm{F}[\mathrm{XRi}] \oplus \mathrm{XRi}-1 ; \\
& \mathrm{XL17}=\mathrm{XR} 16 \oplus \mathrm{P} 1 ; \\
& \mathrm{XR} 17=\mathrm{XL16} \oplus \mathrm{P} 2
\end{aligned}
$$

\section{METODOLOGI PENELITIAN}

\subsection{Perancangan Antarmuka (Interface)}

Perancangan interface adalah bagian yang penting dalam aplikasi karena yang pertama kali dilihat ketika aplikasi dijalankan adalah interface aplikasi. Perancangan antarmuka sendiri terdiri dari perancangan antarmuka menu utama, perancangan antarmuka about dan perancangan antarmuka help. Perancangan antarmuka sendiri menggunakan bahasa XML.

1. Perancangan Antarmuka Menu Utama

Perancangan antarmuka menu utama adalah tampilan yang terdiri dari bagian input file, browse, password, encrypt, decrypt, home, about, help.

2. Perancangan Antarmuka About

Perancangan antarmuka about adalah tampilan yang berisi mengenai penjelasan tentang aplikasi yang telah dibuat.

3. Perancangan Antarmuka Help

Perancangan antarmuka help adalah tampilan yang berisi mengenai penjelasan tentang cara melakukan enkripsi dan dekripsi file.

\subsection{Pembuatan Kelas Encryption}

Kelas encryption ini adalah kelas yang digunakan untuk melakukan proses enkripsi dan dekripsi file. Pada pembuatan program ini, digunakan software Eclipse dengan menggunakan Java. Tampilan pada aplikasi OS Android diatur oleh file XML yang terdapat pada folder res/layout. Tabel 1 merupakan daftar tampilan layout yang telah dibuat. 
Tabel 1. Nama File Layout Beserta Fungsinya

\begin{tabular}{|l|l|}
\hline \multicolumn{1}{|c|}{ Nama File } & \multicolumn{1}{c|}{ Fungsi } \\
\hline about.xml & $\begin{array}{l}\text { Mengatur tampilan } \\
\text { pada halaman } \text { about }\end{array}$ \\
\hline file_view.xml & $\begin{array}{l}\text { Mengatur tampilan } \\
\text { browse file }\end{array}$ \\
\hline footer.xml & $\begin{array}{l}\text { Mengatur tampilan } \\
\text { menu di bawah }\end{array}$ \\
\hline header.xml & $\begin{array}{l}\text { Mengatur tampilan } \\
\text { menu di atas }\end{array}$ \\
\hline help.xml & $\begin{array}{l}\text { Mengatur tampilan } \\
\text { pada halaman help }\end{array}$ \\
\hline main.xml & $\begin{array}{l}\text { Mengatur tampilan } \\
\text { pada halaman awal }\end{array}$ \\
\hline
\end{tabular}

\subsection{Proses Enkripsi File}

Pada tahap ini merancang program untuk mengenkripsi file dengan algoritma Blowfish. Diagram blok untuk proses enkripsi file seperti pada Gambar 2.

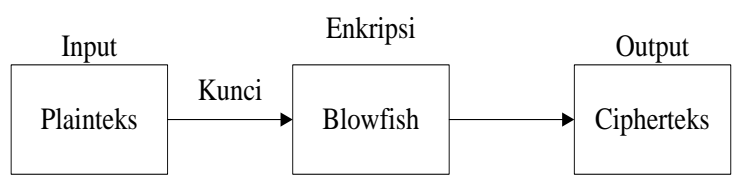

Gambar 2. Diagram Blok Proses Enkripsi File

Gambar 3 memperlihatkan flowchart proses enkripsi file secara keseluruhan. Untuk melakukan proses enkripsi file hal pertama yang dilakukan adalah input plainteks berupa file yang telah ditentukan ukuran dan format filenya.

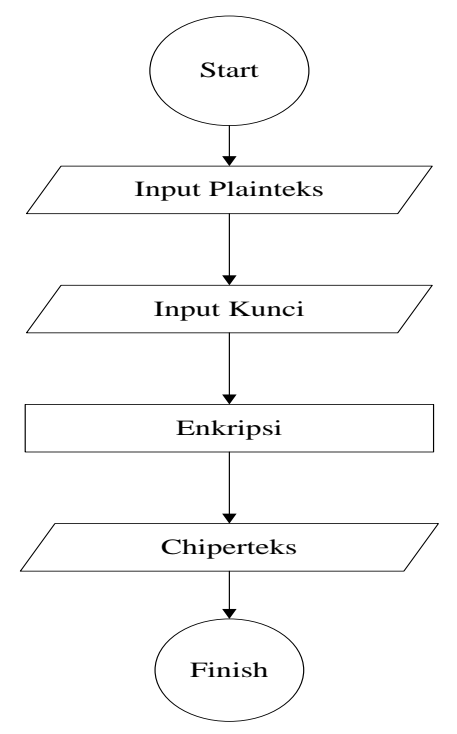

Gambar 3. Flowchart Proses Enkripsi File
Kunci yang digunakan untuk proses enkripsi file bisa berupa gabungan angka, huruf dan karakter khusus sesuai keinginan dari penggunanya. Blowfish sendiri menggunakan kunci simetris dimana kunci untuk enkripsi dan dekripsi sama. Setelah proses enkripsi file berhasil maka hasil outputnya berupa cipherteks yang sudah tidak dapat dimengerti maknanya.

\subsection{Proses Dekripsi File}

Pada tahap ini merancang program untuk mendekripsi file menggunakan algoritma Blowfish. Diagram blok sistem untuk proses dekripsi file diperlihatkan pada Gambar 4.

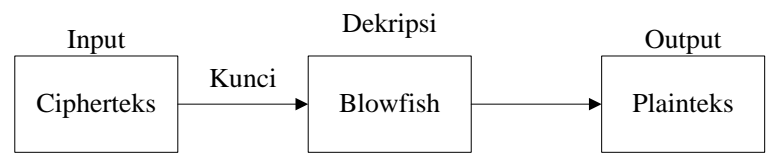

Gambar 4. Diagram Blok Proses Dekripsi File

Gambar 5 memperlihatkan flowchart proses enkripsi file secara keseluruhan. Untuk melakukan proses dekripsi file hal pertama yang dilakukan adalah input cipherteks berupa file yang telah ditentukan ukuran dan format filenya.

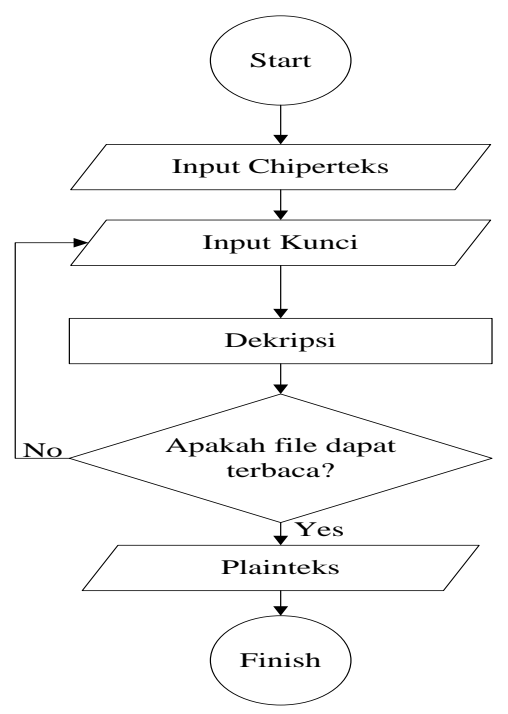

Gambar 5. Flowchart Proses Dekripsi File

Kunci yang digunakan untuk proses enkripsi file bisa berupa gabungan angka, huruf dan karakter khusus sesuai keinginan dari penggunanya. Blowfish sendiri menggunakan kunci simetris dimana kunci untuk enkripsi dan dekripsi sama. Setelah proses dekripsi file 
berhasil maka hasil outputnya berupa plainteks yang bisa dimengerti maknanya.

\section{HASIL DAN PEMBAHASAN}

\subsection{Pengujian Program Aplikasi}

Pada bagian ini dilakukan pengujian aplikasi untuk mengenkripsi file dan setelah proses enkripsi file selesai dilakukan akan dilihat hasilnya kemudian dilakukan pengujian dekripsi file untuk mengembalikan file seperti semula. Pengujian dilakukan dengan format file yang berbeda-beda yang umum terdapat pada perangkat Android. Untuk tingkat keamanannya dilakukan terhadap serangan brute force.

\subsubsection{Pengujian Terhadap Ukuran File}

Hasil pengujian terhadap file-file yang telah ditentukan sebelumnya dari berbagai macam format file dapat dilihat pada Tabel 2 yang menunjukkan hasil ukuran file setelah dilakukan proses enkripsi file dan Tabel 3 yang menunjukkan hasil ukuran file setelah dilakukan proses dekripsi file.

Setelah file didekripsi kembali ukuran file akan sama seperti semula. Hal ini menunjukan aplikasi ini dapat bekerja dengan baik.

Tabel 2. Hasil Proses Enkripsi beberapa format file yang berbeda

\begin{tabular}{|c|l|c|c|}
\hline No & Nama file plainteks & $\begin{array}{c}\text { Ukuran } \\
\text { file } \\
\text { plainteks } \\
\text { (Byte) }\end{array}$ & $\begin{array}{c}\text { Ukuran } \\
\text { file } \\
\text { ciphertek } \\
\text { S (Byte) }\end{array}$ \\
\hline 1 & $\begin{array}{l}\text { Algoritma dan } \\
\text { Flowchart.pptx }\end{array}$ & 1528716 & 1528720 \\
\hline 2 & $\begin{array}{l}\text { Berapa Lama Waktu } \\
\text { Bongkar Password.doc }\end{array}$ & 117248 & 117256 \\
\hline 3 & $\begin{array}{l}\text { Cara Merubah } \\
\text { Background Pas } \\
\text { Foto.mp4 }\end{array}$ & 4910554 & 4910560 \\
\hline 4 & Fellaini.jpg & 334713 & 334720 \\
\hline 5 & $\begin{array}{l}\text { LIST SILABUS } \\
\text { CCNA } \\
\text { EXPLORATION.txt }\end{array}$ & 1114 & 1120 \\
\hline 6 & $\begin{array}{l}\text { MAC Random Access } \\
\text { 10.pptx }\end{array}$ & 442168 & 442176 \\
\hline 7 & $\begin{array}{l}\text { Matematika Teknik 2 } \\
\text { excel 97-2003.xls }\end{array}$ & 151552 & 151560 \\
\hline 8 & Motorola Charm.jpg & 201285 & 201288 \\
\hline 9 & Paper Aes.pdf & 673435 & 673440 \\
\hline 10 & $\begin{array}{l}\text { Sejarah Adobe } \\
\text { Photoshop.pdf }\end{array}$ & 1130348 & 1130352 \\
\hline
\end{tabular}

Ukuran file setelah dienkripsi lebih besar dari ukuran asli disebabkan karena adanya proses padding yaitu untuk memperoleh blok terakhir sebesar 64 bit. Panjang password/key untuk melakukan pengujian ini adalah 9 karakter yang terdiri dari kombinasi huruf dan angka. Key yang digunakan untuk ujicoba adalah qwerty 123 .

Tabel 3. Hasil Proses Dekripsi beberapa format file yang berbeda

\begin{tabular}{|c|l|c|c|}
\hline No & \multicolumn{1}{|c|}{$\begin{array}{c}\text { Nama } \\
\text { file plainteks }\end{array}$} & $\begin{array}{c}\text { Ukuran } \\
\text { file } \\
\text { ciphertek } \\
\text { s (Byte) }\end{array}$ & $\begin{array}{c}\text { Ukuran } \\
\text { file } \\
\text { plainteks } \\
\text { (Byte) }\end{array}$ \\
\hline 1 & $\begin{array}{l}\text { Algoritma dan } \\
\text { Flowchart.pptx }\end{array}$ & 1528720 & 1528716 \\
\hline 2 & $\begin{array}{l}\text { Berapa Lama Waktu } \\
\text { Bongkar Password.doc }\end{array}$ & 117256 & 117248 \\
\hline 3 & $\begin{array}{l}\text { Cara Merubah } \\
\text { Background Pas }\end{array}$ & 4910560 & 4910554 \\
\hline 4 & Foto.mp4 & 334720 & 334713 \\
\hline 5 & $\begin{array}{l}\text { Fellaini.jpg } \\
\text { CCNA } \\
\text { EXPLORATION.txt }\end{array}$ & 1120 & 1114 \\
\hline 6 & $\begin{array}{l}\text { MAC Random Access } \\
\text { 10.pptx }\end{array}$ & 442176 & 442168 \\
\hline 7 & $\begin{array}{l}\text { Matematika Teknik } 2 \\
\text { excel 97-2003.xls }\end{array}$ & 151560 & 151552 \\
\hline 8 & Motorola Charm.jpg & 201288 & 201285 \\
\hline 9 & Paper Aes.pdf & 673440 & 673435 \\
\hline 10 & $\begin{array}{l}\text { Sejarah Adobe } \\
\text { Photoshop.pdf }\end{array}$ & 1130352 & 1130348 \\
\hline & & & \\
\hline
\end{tabular}

\subsubsection{Pengujian Enkripsi Terhadap \\ Beberapa Tipe File}

Ujicoba enkripsi dan dekripsi yang telah dilakukan pada file yang berformat (.pptx), (.doc), (.mp4), (.jpg), (.txt), (.xls) dan (.pdf).

1. File .txt

Untuk pengujian pada file (.txt) dengan nama file LIST SILABUS CCNA EXPLORATION.txt dengan menggunakan password "qwerty123" untuk enkripsi dan dekripsinya. Plainteksnya ditunjukkan pada Gambar 6 (a) dengan ukuran file sebesar 1114 Byte. Hasil enkripsinya ditunjukkan pada Gambar 6 (b) dengan ukuran file sebesar 1120 Byte atau lebih besar 6 Byte dari ukuran aslinya.

2. File .jpg

Untuk pengujian pada file (.jpg) dengan nama file Motorola Charm.jpg dengan menggunakan 
password "qwerty123" untuk enkripsi dan dekripsinya. Plainteksnya ditunjukkan pada Gambar 7 (a) dengan ukuran file sebesar 201285 Byte. Hasil enkripsinya ditunjukkan pada Gambar 7 (b) dengan ukuran file sebesar 201288 Byte atau lebih besar 3 Byte dari ukuran aslinya.

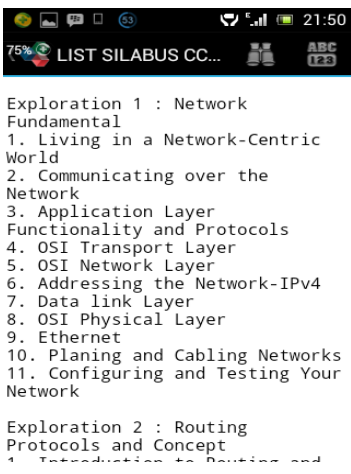

(a)

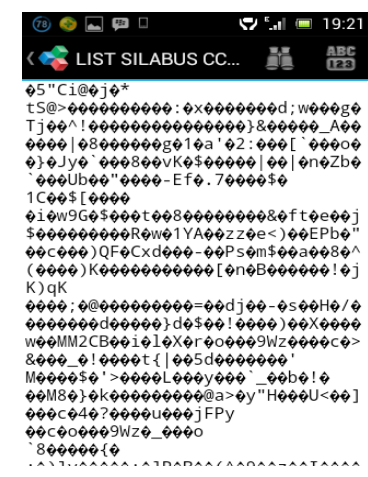

(b)
Gambar 6. Plainteks (a) dan Cipherteks (b) dari file berformat txt

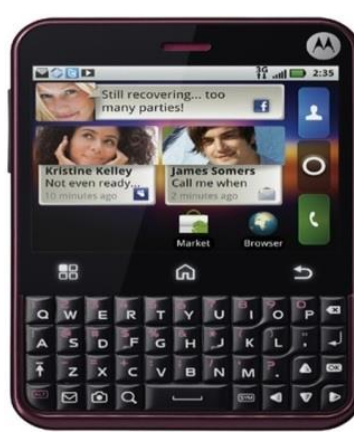

(a)

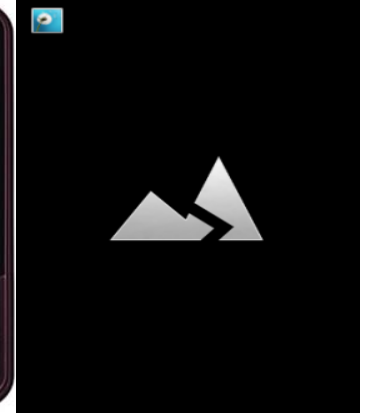

(b)
Gambar 7. Plainteks (a) dan Cipherteks (b) dari file berformat .jpg

\section{File.pptx}

Untuk pengujian pada file (.pptx) dengan nama file MAC Random Access 10.pptx dengan menggunakan password "qwerty123" untuk enkripsi dan dekripsinya. Plainteksnya ditunjukkan pada Gambar 8 (a) dengan ukuran file sebesar 442168 Byte. Hasil enkripsinya ditunjukkan pada Gambar 8 (b) dengan ukuran file sebesar 442176 Byte atau lebih besar 8 Byte dari ukuran aslinya. Hasil enkripsinya berupa file yang tidak bisa dibaca kembali.

4. File.pdf

Untuk pengujian pada file (.pdf) dengan nama file Paper Aes.pdf dengan menggunakan password "qwerty123" untuk enkripsi dan dekripsinya. Plainteksnya ditunjukkan pada Gambar 9 (a) dengan ukuran file sebesar 673435 Byte. Hasil enkripsinya ditunjukkan pada Gambar 9 (b) dengan ukuran file sebesar 673440 Byte atau lebih besar 5 Byte dari ukuran aslinya. Hasil enkripsinya berupa file yang tidak bisa dibaca kembali.

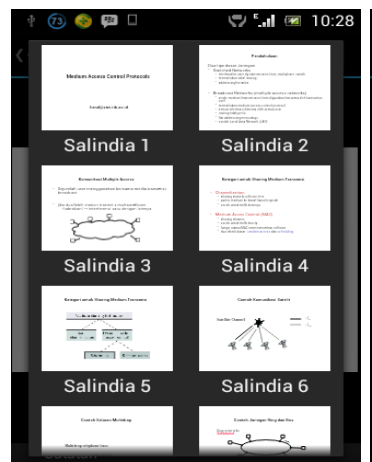

(a)

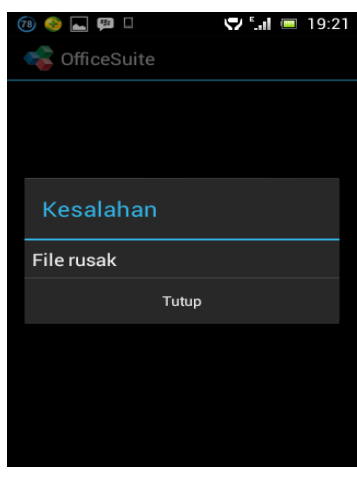

(b)
Gambar 8. Plainteks (a) dan Cipherteks (b) dari file berformat .pptx

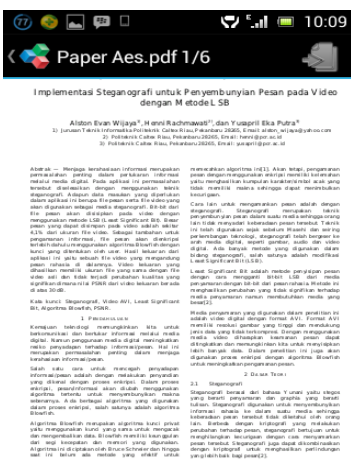

(a)

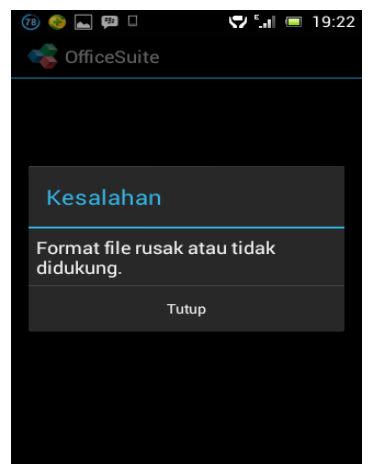

(b)
Gambar 9. Plainteks (a) dan Cipherteks (b) dari file berformat .pdf

\section{File.mp4}

Untuk pengujian pada file (.mp4) dengan nama file Cara Merubah Background Pas Foto.mp4 dengan menggunakan password "qwerty123" untuk enkripsi dan dekripsinya. Plainteksnya ditunjukkan pada Gambar 10 (a) dengan ukuran file sebesar 4910554 Byte. Hasil enkripsinya ditunjukkan pada Gambar 10 (b) dengan ukuran file sebesar 4910560 Byte atau lebih besar 6 Byte dari ukuran aslinya. 


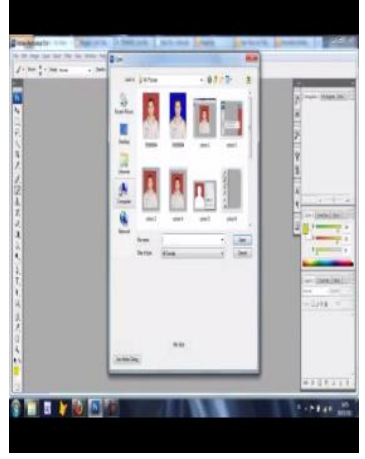

(a)

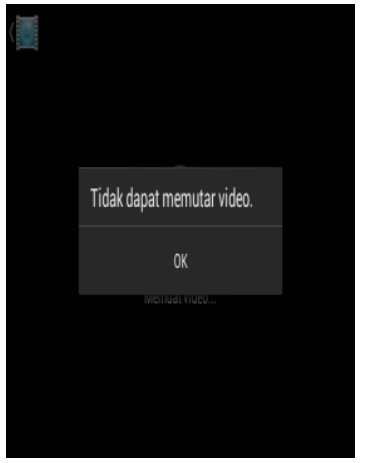

(b)
Gambar 10. Plainteks (a) dan Cipherteks (b) dari file berformat .mp4

\section{File .xls}

Untuk pengujian pada file (.xls) dengan nama file Matematika Teknik 2 excel 97-2003.xls dengan menggunakan password "qwerty123" untuk enkripsi dan dekripsinya. Plainteksnya ditunjukkan pada Gambar 11 (a) dengan ukuran file sebesar 151552 Byte. Hasil enkripsinya ditunjukkan pada Gambar 11 (b) dengan ukuran file sebesar 151560 Byte atau lebih besar 8 Byte dari ukuran aslinya.

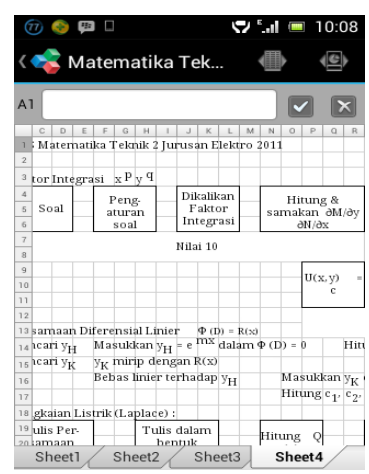

(a)

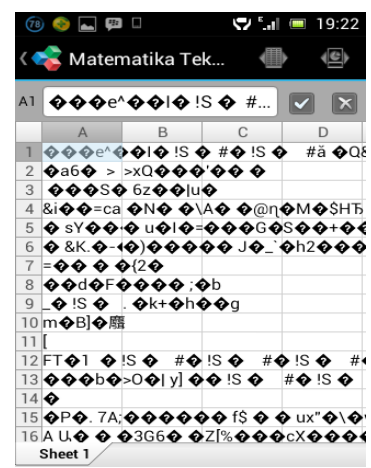

(b)
Gambar 11. Plainteks (a) dan Cipherteks (b) dari file berformat .xls

\section{File.doc}

Untuk pengujian pada file (.doc) dengan nama file Berapa Lama Waktu Bongkar Password.doc dengan menggunakan password "qwerty123" untuk enkripsi dan dekripsinya. Plainteksnya ditunjukkan pada Gambar 12 (a) dengan ukuran file sebesar 117248 Byte. Hasil enkripsinya ditunjukkan pada Gambar 12 (b) dengan ukuran file sebesar 117256 Byte atau lebih besar 8 Byte dari ukuran aslinya.

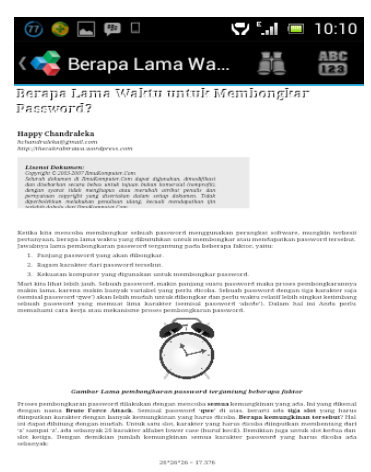

(a)

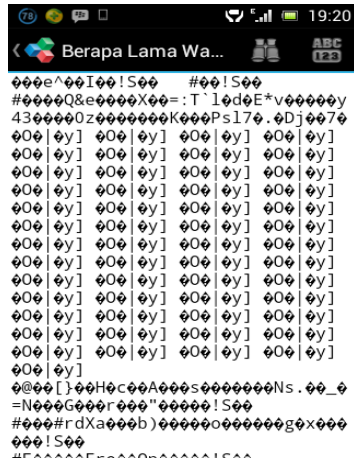

(b)
Gambar 12. Plainteks (a) dan Cipherteks (b) dari file berformat .doc

Dari hasil pengujian aplikasi terhadap filefile yang telah ditentukan format filenya, rancangan proses enkripsi pada file tersebut yang telah dirancang dapat diimplementasikan dan berhasil dijalankan dengan baik. Hal ini dibuktikan dengan aplikasi yang bisa diinstal ke dalam handphone Android dan dapat digunakan untuk melakukan proses enkripsi dan dekripsi file. Password/key digunakan harus sama karena algoritma Blowfish menggunakan kunci simetris untuk melakukan proses enkripsi dan dekripsi file. Proses dekripsi file dengan password/key yang salah tidak dapat membuka file kembali seperti keadaan semula. Untuk itu pengguna aplikasi ini disarankan untuk mengingat dengan baik password/key yang digunakan. Jika pengguna lupa password/key maka file tidak dapat didekripsi lagi. Panjang password/key dan kerahasiaan password/key mempengaruhi dari tingkat keamanan file itu sendiri.

Untuk tingkat keamanan dilakukan pengujian terhadap serangan brute force. Serangan bertipe brute force adalah dengan menerapkan percobaan setiap kemungkinan kunci yang ada satu per satu sampai diperoleh plainteks yang diharapkan. Waktu yang diperlukan untuk memperoleh kunci yang diharapkan, selalu berbanding lurus dengan panjang bit kunci yang dimiliki oleh algoritma kriptografi, dan makin cepat prosesor yang dipakai, makin cepat waktu yang pula dibutuhkan untuk dapat memperoleh kunci tersebut. Analisa brute force attack pada sistem ini adalah dengan melakukan perhitungan matematis dari masing-masing kunci untuk mendapatkan nilai durasi proses memecahkan kemungkinan kunci. Panjang kunci yang digunakan dalam penelitian ini adalah 72 bit. 
Kemungkinan kunci yang dapat dihasilkan dengan menggunakan panjang 72 bit adalah sejumlah 4,7 x $10^{21}$ kunci. Asumsi kecepatan komputasi adalah $10^{6} \mathrm{key} / \mathrm{sec}$ maka :

$$
\frac{4,7 \times 10^{21}}{10^{6}}=\frac{4,7 \times 10^{15} \mathrm{sec}}{3,1536 \times 10^{7}}=1,49 \times 10^{8}
$$

menghasilkan durasi sejumlah $1,49 \times 10^{8}$ tahun untuk memecahkan seluruh kemungkinan kunci.

Berdasarkan dari hasil pengujian tersebut, maka aplikasi enkripsi dan dekripsi file ini aman untuk melindungi file-file yang sifatnya pribadi dan rahasia yang orang lain tidak berhak untuk mengetahuinya.

\section{KESIMPULAN}

Berdasarkan pengujian dan analisis yang telah dilakukan Aplikasi enkripsi dan dekripsi file dapat berfungsi dengan baik pada handphone Android dengan OS Android 2.3, 4.0, dan 4.1. Aplikasi yang dibuat dapat diimplementasikan dengan baik untuk melakukan enkripsi dan dekripsi file karena file yang telah dienkripsi menjadi tidak bisa dimengerti dan pahami lagi isinya. Tingkat keamanan dari aplikasi yang dibuat cukup aman karena algoritma Blowfish memiliki panjang kunci yang besar. Dengan menggunakan kunci berjumlah 72 bit atau 9 karakter dibutuhkan waktu $1,49 \times 10^{8}$ tahun untuk membongkarnya dengan kecepatan komputasinya adalah $10^{6}$ $\mathrm{key} / \mathrm{sec}$.

Diharapkan kedepan sistem aplikasi ini bisa dikembangkan menjadi lebih baik lagi seperti menambahkan beberapa fitur diantaranya penambahan pilihan algoritma lain dan kemampuan untuk mengenkripsi folder. Pembuatan fungsi waktu sehingga bisa diketahui seberapa cepat enkripsi dan dekripsi filenya. Untuk mengetahui tingkat keamanan, perlu dilakukan pula uji sniffing di jaringan komputer.

\section{DAFTAR PUSTAKA}

[1] Wardoyo, Siswo, Taufik Ryadi, dan Rian Fahrizal. "Analisis Performa File Transport Protocol Pada Perbandingan Metode IPv4 Murni, IPv6 Murni dan Tunneling 6to4 Berbasis Router Mikrotik." Jurnal Nasional Teknik
Elektro, Vol 3. no 2, 2014.

[2] Mukti, Prasetiyono Hari, Rizki Aris Yunianto, dan Achmad Affandi. "Evaluasi Kinerja Layanan IPTV pada Jaringan Testbed WiMAX Berbasis Standar IEEE 802.16-2004". Jurnal Nasional Teknik Elektro, Vol 4. no 2, 2015.

[3] D. T. Massandy, "Studi dan Implementasi Cryptography Package pada Sistem Operasi Android," no. 13508051, 2011.

[4] C. A. Sutanto, "Penggunaan Algoritma Blowfish dalam Kriptografi," Bandung, Indonesia, 2010.

[5] E.A.Shanty, "Implementasi Algoritma Kriptografi Blowfish Untuk Keamanan Dokumen Pada Microsoft Office," $J$. Chem. Inf. Model., vol. 53, no. 9, pp. 1689-1699, 2013.

[6] A. Rahman, T. Maskes, "Implementasi Algoritma Serpent Untuk Enkripsi Dan Dekripsi Data File Pada Ponsel," J. Jur. Tek. Inform. STMIK GI MDP, 2013.

[7] I. Rahmayun, D. Jurusan, T. Informasi, and P. Negeri, "Enkripsi SMS ( SHORT MESSAGE SERVICE ) Pada Telepon Selular Berbasis Android Dengan Metode RC6," J. Momentum, vol. 16, no. 1, pp. 63-73, 2014.

[8] R. Munir, Kriptografi. Bandung, Indonesia: Penerbit Informatika Bandung, 2006.

[9] R. Munir, "Diktat Kuliah IF5054 Kriptografi," Bandung, Indonesia, 2004.

[10] Tetuko, P.N, A. Qoiriah, "Rancang Bangun Aplikasi Enkripsi Database MYSQL Dengan Algoritma BLOWFISH," J. Manejemen Inform., vol. 02, no. 01, pp. 39-44, 2013.

[11] S. Sitinjak and Y. Fauziah, "Aplikasi Kriptografi File Menggunakan," vol. 2010, no. semnasIF, pp. 78-86, 2010.

[12] A. E Pratiwi, "Implementasi Enkripsi Data Dengan Algoritma Blowfish Menggunakan Java Pada Aplikasi Email," J. Jur. Tek. Komput. Bandung, 2011.

\section{Biodata Penulis}

Siswo Wardoyo, lahir di Boyolali tanggal 07 Maret 1978 Pendidikan S1 di Jurusan Teknik Elektro Universitas Diponegoro Semarang pada tahun 2002. Pendidikan S2 di Jurusan Teknik 
Elektro Universitas Gadjah Mada Yogyakarta dengan Program Studi Teknik Elektro pada tahun 2008. Sekarang menjadi staff pengajar di Jurusan Teknik Elektro, Universitas Sultan Ageng Tirtayasa, Cilegon, Banten, Indonesia. 